OвJECTIVE: The influence of a macrolide antibiotic, roxithromycin (RXM), on co-stimulatory molecule expression was examined in vitro and in vivo.

Materials and metbods: Spleen cells obtained from BALB/c mice 10 days after immunization with $8.0 \mu \mathrm{g}$ of hemocyanin absorbed to $4.0 \mathrm{mg}$ of aluminum hydroxide were cultured in the presence of $100.0 \mu \mathrm{g} / \mathrm{ml}$ of hemocyanin and various concentrations of RXM. We first examined the influence of RXM on cell activation by examining the proliferative response of cells and cytokine production. We also examined the influence of RXM on co-stimulatory molecule (CD40, CD80 and CD86) expressions on cultured splenic B-lymphocytes induced by in vitro antigenic stimulation using flow cytometry. In the second part of experiments, non-immunized and immunized mice were treated orally with $2.5 \mathrm{mg} / \mathrm{kg}$ of RXM once a day for 4 or 8 weeks. Splenic $B$ lymphocytes were obtained from these mice $24 \mathrm{~h}$ after antigenic challenge, and co-stimulatory molecule expressions were examined by flow cytometer. Results: Cell activation induced by in vitro antigenic stimulation was suppressed by RXM when cells were cultured in the presence of more than $5.0 \mu \mathrm{g} / \mathrm{ml}$ of the agent. Addition of RXM at a concentration of $5.0 \mu \mathrm{g} / \mathrm{ml}$ into cell cultures also suppressed co-stimulatory molecule (CD40, CD80 and CD86) expressions on splenic B lymphocytes, which was enhanced by antigenic stimulation in vitro. Oral RXM administration for 4 weeks clearly suppressed the enhancement of CD40 and CD86 (but not CD80) expressions on splenic B lymphocytes induced by antigenic stimulation in vivo. This suppressive activity of RXM on costimulatory molecule (CD40 and CD86) expressions was further strengthened by the treatment of mice for 8 weeks. Long-term treatment with oral RXM also suppressed CD80 expressions, which was not suppressed by 4 -week treatment.

Conclusion: The present results suggest that RXM exerts its immunomodulating effects through suppression of both cell activation and co-stimulatory molecule expressions induced by antigenic stimulation. These suppressive activities of RXM might contribute, in part, to the therapeutic mode of action of RXM on inflammatory diseases.

Key words: Roxithromycin, Mouse, Splenic B lymphocytes, Co-stimulatory molecule, Inhibition, In vitro, In vivo.

\section{Inhibitory action of a macrolide antibiotic, roxithromycin, on co-stimulatory molecule expressions in vitro and in vivo}

\author{
Mayumi Suzuki ${ }^{1}$, Kazuhito Asano ${ }^{2, C A}$, Mei Yu ${ }^{1}$, \\ Tadashi Hisamitsu² and Harumi Suzaki ${ }^{1}$
}

${ }^{1}$ Department of Otolaryngology, and ${ }^{2}$ Department of Physiology, School of Medicine, Showa University, Shinagawa-ku, Tokyo 142-8555, Japan

${ }^{\mathrm{CA}}$ Corresponding author
Tel: +81337848110
Fax: +81337845368
E-mail: asanok@med.showa-u.ac.jp

\section{Introduction}

Long-term administration of 14-membered macrolide antibiotics has been reported to favorably modify the clinical conditions of chronic inflammatory diseases including chronic sinusitis, diffuse panbronchiolitis, and bronchial asthma. ${ }^{1-5}$ This treatment is called macrolide therapy and is used frequently in the treatment of inflammatory diseases, especially in Japan. $^{4,5}$ More recently, clinical trial therapy in
England revealed that long-term administration (more than 3 months) of azithromycin, a newly synthesized macrolide antibiotic, into patients with cyctic fibrosis can improve lung functions. ${ }^{6,7}$

Much effort has been made to understand the mechanisms underlying the efficacy of macrolide therapy, and has revealed that erythromycin, the most famous macrolide antibiotic, could inhibit chemotaxis and generation of inflammatory mediators such as $\mathrm{O}_{2}^{-}$and $\mathrm{H}_{2} \mathrm{O}_{2}$ by neutrophils when the 
cells were cultured in vitro in the presence of agent. ${ }^{8}$ Furthermore, oral administration of roxithromycin (RXM) once a day for more than 3 weeks has been shown to be able to suppress the ability of lymphocytes to produce inflammatory cytokines, such as interleukin (IL)-1 $\beta$, in response to mitogenic and antigenic stimulation. ${ }^{9,10}$ Judging from these reports, there is a possibility that macrolide antibiotics inhibit the development of inflammatory responses and result in favorable modification of the clinical conditions of patients with inflammatory diseases.

There is enough evidence that $\mathrm{T}$ cells play a central role in initiation, driving and maintenance of inflammatory responses through the secretion of several types of cytokines. ${ }^{9,11}$ It is now also established that the CD28/B7 co-stimulatory pathway is essential for T-cell activation, proliferation and cytokine secretion. ${ }^{12,13} \mathrm{~A}$ number of studies have clearly demonstrated that expressions of the co-stimulatory molecules (CD80 and CD86) on peripheral blood leukocytes from patients with inflammatory diseases were upregulated compared with normal subjects. $^{14-16}$ It is also reported that CD80 and CD86 expressions on $\mathrm{B}$ cells were enhanced when the cells prepared from atopic patients and pollinosis subjects were stimulated with specific antigen in vitro. ${ }^{17,18}$ In mouse models for inflammatory diseases, treatment of mice with anti-CD80 and antiCD86 monoclonal antibodies (mAbs) reduced several parameters of inflammatory responses such as eosinophilia and IgE hyper-production. ${ }^{19-21}$ Although these reports suggest the importance of co-stimulatory molecules in the induction and the development of the inflammatory diseases, there is little information about the influence of RXM on costimulatory molecule expressions. ${ }^{22}$ The present study, therefore, was undertaken to examine whether RXM could modulate the expression of costimulatory molecules on lymphocytes in vitro and in vivo.

\section{Materials and methods}

\section{Mice}

Specific pathogen free male BALB/c mice, 5 weeks of age, were purchased from Charles River Japan Inc. (Atsugi, Japan). After arrival at our university, they were kept in filter $(0.2 \mu \mathrm{m})$-barriered cages, and provided with autoclaved food and tap water ad libitum throughout the experiments to prevent unwanted microbiological infection. Each experimental and control group consisted of five mice. All animal experimental procedures were approved by the Animal Care and Use Committee of Showa University, and were carried out in accordance with the guidelines of the Physiological Society of Japan.

\section{Monoclonal antibodies (mAbs)}

mAbs to block T-cell stimulation were anti-mouse CD80 and CD86 antibodies (PharMingen, San Diego, CA, USA). All these mAbs were used free of $\mathrm{NaN}_{3}$. The mAbs used for flow cytometric analysis were as follows; fluorescein isothiocyanate (FITC)-conjugated anti-mouse CD40 mAb (hamster IgM), FITC-conjugated anti-mouse CD80 mAb (hamster IgG), FITCconjugated anti-mouse CD86 $\mathrm{mAb}$ (rat IgG2a) and anti-mouse CD16/CD32 mAb. They were purchased from PharMingen and contained $0.1 \% \mathrm{NaN}_{3}$.

\section{Agents}

RXM was kindly donated from Aventis Pharm Co., Ltd. (Tokyo, Japan) as preservative-free pure powders. RXM was dissolved in $100 \%$ methyl alcohol at a concentration of $20.0 \mathrm{mg} / \mathrm{ml}$ and then diluted with the culture medium at a concentration of $100 \mu \mathrm{g} / \mathrm{ml}$. This solution was sterilized by passing through a $0.22 \mu \mathrm{m}$ filter and stored as a stock solution at $4^{\circ} \mathrm{C}$ until used. All dilutions used in in vitro study were prepared from this stock solution. For in vivo use, RXM dissolved in $100 \%$ methyl alcohol $(20.0 \mathrm{mg} / \mathrm{ml})$ was diluted with sterile saline to give a concentration of $250 \mu \mathrm{g} / \mathrm{ml}$.

\section{Immunization}

Mice were immunized by intraperitoneal injection with $8.0 \mu \mathrm{g}$ of hemocyanin (Sigma Chemical Co., St Louis, MO, USA) absorbed to $4.0 \mathrm{mg}$ of aluminum hydroxide (Wako Chemical Co., Ltd., Osaka, Japan) in a volume of $0.5 \mathrm{ml}$ of saline.

\section{Treatment of mice with RXM}

Mice were treated orally with RXM at a dose of $2.5 \mathrm{mg} / \mathrm{kg}$ once a day for 4 or 8 weeks, starting 7 days after the immunization.

\section{Cell preparation}

Spleen was removed from mice killed under ether anesthesia. The organs were pressed through 60-gauge stainless steel meshes into saline. The cells were washed once with saline and resuspended in Tris-buffered ammonium chloride (17 mM Tris-HCI, $0.73 \% \mathrm{NH}_{4} \mathrm{CI} ; \mathrm{pH} 7.6$ ) to lyse red blood cells. After passing through a 200-gauge steel sieve, the cells were washed five times with RPMI-1640 medium (WAKO Chemical) supplemented with $10 \%$ heatinactivated fetal calf serum (SIGMA Chemical) at a concentration of $5 \times 10^{6} \mathrm{cells} / \mathrm{ml}$. In the case of experiments using purified $T$ cells and $B$ cells, these cells were separated from spleen cells using a magnetic cell separator (Miltenyi Biotec GmbH, 
Bergisch Gladbach, Germany) as described previously. ${ }^{23}$ The purity of cells was checked by incubating separated cells with FITC-conjugated mAb to CD90 (PharMingen). Fluorescence microscopic examination revealed that the percentage of contaminated cells in each fractionated populations was less than $2 \%$, respectively. CD90-positive cells were used as T cells and CD90-negative cells as B cells.

\section{Cell culture and culture supernatant}

To examine blastic activity of the cells to antigenic stimulation, cells prepared from mice 10 days after immunization $\left(1 \times 10^{5}\right.$ cells $\left./ 100 \mu \mathrm{l}\right)$ were added to the wells of 96-well flat-bottomed microtiter plates, which contained various concentrations of RXM and $100.0 \mu \mathrm{g} / \mathrm{ml}$ of hemocyanin in a final volume of $200 \mu \mathrm{l}$. The plates were maintained for $72 \mathrm{~h}$ at $37^{\circ} \mathrm{C}$ in a humidified atmosphere with $5 \% \mathrm{CO}_{2}$. Cell proliferation was assessed by adding $1.0 \mu \mathrm{Ci}$ of ${ }^{3} \mathrm{H}$-thymidine for the final $8 \mathrm{~h}$ of the culture. Incorporation of ${ }^{3} \mathrm{H}$-thymidine was measured with a Packard Tricarb liquid scintillation counter and the results were expressed as mean counts per minute (CPM) \pm standard error of triplicate cultures. To examine the effects of anti-CD80 and anti-CD86 mAbs on antigeninduced cell proliferation, each $\mathrm{mAb}$ was added at the concentration of $5.0 \mu \mathrm{g} / \mathrm{ml}$ to the cultures from the beginning. In the case of examining blastic activity of cells to anti-CD3 mAb stimulation, $100 \mu 1$ of T-cell suspension $\left(2 \times 10^{5}\right.$ cells $)$ was introduced into each well of 96-well flat-bottomed plates, which was coated with $20.0 \mu \mathrm{g} / \mathrm{ml}$ of mAb to mouse $\mathrm{CD}_{\varepsilon}$ as previously described. ${ }^{23,24}$ Various concentrations of RXM were then added in another $100 \mu 1$ to give a total volume of $200 \mu 1$. The cell proliferation was assessed in a similar manner. For examination of the influence of RXM on co-stimulatory molecule expressions, cell suspensions $\left(5 \times 10^{5}\right.$ cells $)$ were dispensed into 24-well plates that contained $0.5 \mathrm{ml}$ of $5.0 \mu \mathrm{g}$ RXM and $100.0 \mu \mathrm{g} / \mathrm{ml}$ antigen. The plates were maintained for $24 \mathrm{~h}$ at $37^{\circ} \mathrm{C}$ in a humidified atmosphere with $5 \%$ $\mathrm{CO}_{2}$ in air. The cells were then collected, washed twice with saline, resuspended and stored on ice until processed. To prepare culture supernatants, cells were cultured for $24 \mathrm{~h}$ in a similar manner. Culture supernatants were obtained after pelleting cells by centrifugation at $3000 \mathrm{rpm}$ for $10 \mathrm{~min}$ at $4^{\circ} \mathrm{C}$.

\section{Assay for cytokines}

IL- 4 and IL-5 concentrations in culture supernatants were assayed using the commercially available mouse cytokine enzyme linked immunosorbent assay (ELISA) Test Kits (R \& D systems, Inc., Minneapolis, MN, USA). The ELISA was coined out in duplicate according to the manufacturer's protocol. The minimum detectable level of each ELISA kit is less than $2 \mathrm{pg} / \mathrm{ml}$.
Assay for serum $\lg E$

The blood was obtained from mice by cardiac puncture under ether anesthesia $24 \mathrm{~h}$ after the second immunization ( 4 or 8 weeks after the first immunization). After clotting, the serum was obtained, and total serum IgE levels were measured in duplicate by mouse IgE enzyme immunoassay kits (YAMASA Co. Ltd., Chiba, Japan) according to the manufacturer's recommended procedures. The sensitivity of this assay kit is less than $5 \mathrm{ng} / \mathrm{ml}$.

\section{Flow cytometry}

The purified cultured B cells were treated with $1.0 \mu \mathrm{g}$ of anti-mouse CD16/CD32 $\mathrm{mAb}$ for $5 \mathrm{~min}$ at $4^{\circ} \mathrm{C}$ to block non-specific Fc receptor-mediated binding of antibodies. Pre-treated cells were then stained with either FITC-conjugated mAb to CD40, CD80 or CD86 for $25 \mathrm{~min}$ at $25^{\circ} \mathrm{C}$. After washing once, cells were suspended in saline, and assayed for fluorescent intensity on cells using a flow cytometer (EPICS ALTRA $^{\mathrm{TM}}$; Beckman Coulter Company, Miami, FL, USA)

\section{Statistical analysis}

Analysis of variance, combined with Fisher's PLSD test, was performed to determine the statistical significance.

\section{Results}

\section{Influence of RXM on spleen cell activation}

The first set of experiments was undertaken to examine the influence of RXM on cell activation induced by in vitro stimulation with antigen. Spleen cells prepared from five individual mice immunized with hemocyanin 10 days before were cultured with $100.0 \mu \mathrm{g} / \mathrm{ml}$ of hemocyanin and various concentrations of RXM for $72 \mathrm{~h}$. As shown in Fig. 1A, low concentrations of RXM did not affect the proliferative responses of spleen cells to hemocyanin stimulation. However, addition of RXM to the cultures at more than $5.0 \mu \mathrm{g} / \mathrm{ml}$ caused a statistically significant inhibition of the proliferative responses of spleen cells (Fig. 1A). The next experiments were undertaken to examine whether the suppressive activity of RXM on antigen-induced cell activation was also observed in cells stimulated by anti-CD3 mAb. Immunized splenic $\mathrm{T}$ cells were cultured with immobilized $\mathrm{mAb}$ in the presence of various concentrations of RXM for $72 \mathrm{~h}$. The data in Fig. 1B show that RXM did not interfere with the proliferative response of $\mathrm{T}$ cells even when the cells were cultured with $10.0 \mu \mathrm{g} / \mathrm{ml}$ of RXM. The third experiments were designed to assess the influence of RXM on antigen-specific cell activation by examining the cytokine levels in culture supernatants. 


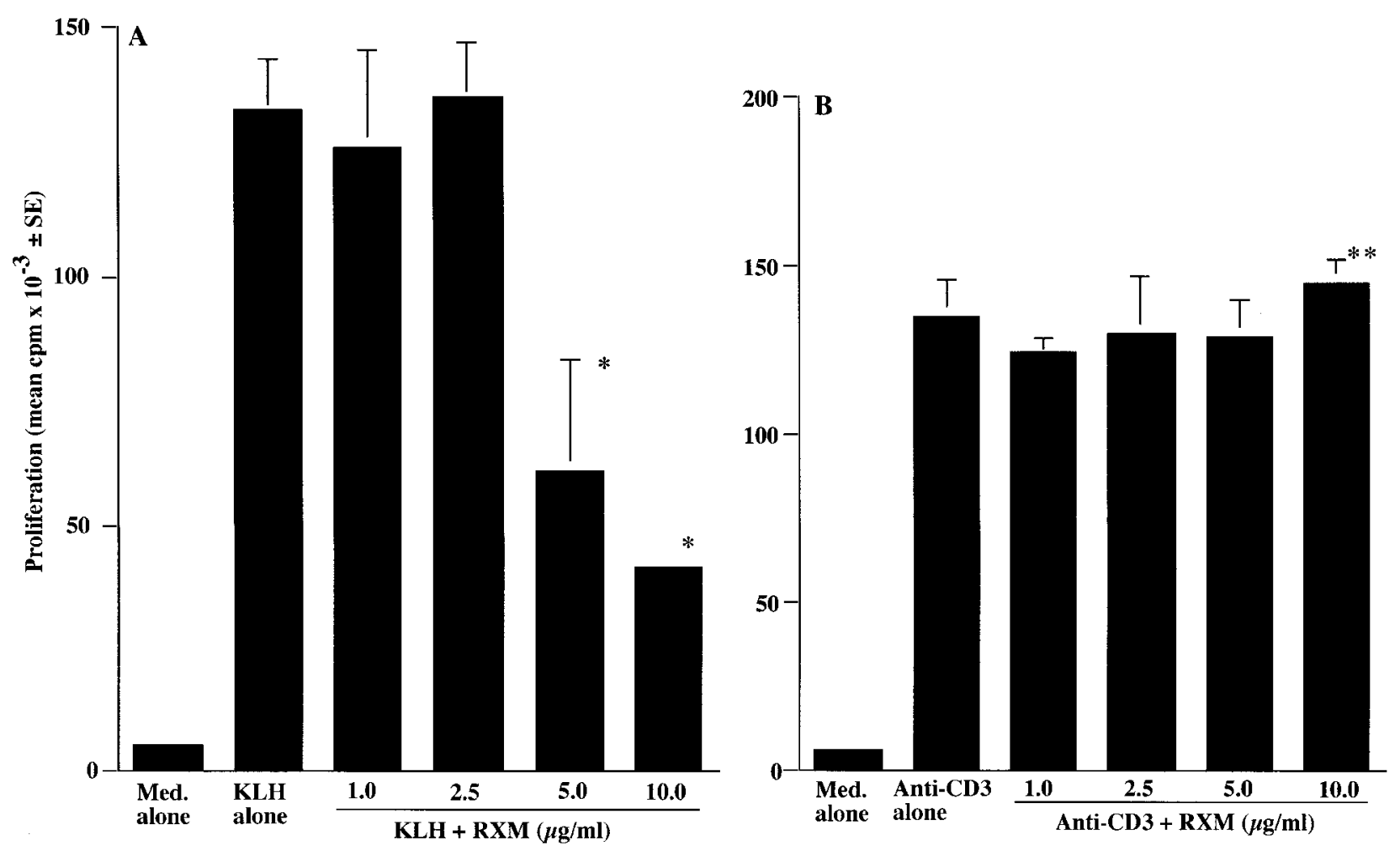

FIG. 1. Influence of RXM on antigen-induced proliferative response of splenic lymphocytes. BALB/c mice were immunized by intraperitoneal injection with $8.0 \mu \mathrm{g} / \mathrm{ml}$ of hemocyanin $\mathrm{KLH}$ absorbed to $4.0 \mathrm{mg}$ of aluminum hydroxide in a volume of $0.5 \mathrm{ml}$. Spleen cells $\left(1 \times 10^{5} \mathrm{cells} / 0.1 \mathrm{ml}\right)$ prepared from mice 10 days later were cultured in the presence of various concentrations of RXM for $72 \mathrm{~h}$, which were stimulated with $100.0 \mu \mathrm{g} / \mathrm{ml}$ of KLH (A). Splenic T cells $\left(2 \times 10^{5}\right.$ cells $\left./ 0.1 \mathrm{ml}\right)$ were also cultured with immorbilized anti-CD3 $\varepsilon_{\varepsilon}$ monoclonal antibody in the presence of various concentrations of RXM for $72 \mathrm{~h}$ (B). The cell proliferation was assessed by measuring incorporation of $1.0 \mu \mathrm{Ci}$ of ${ }^{3} \mathrm{H}$-thymidine for $8 \mathrm{~h}$. The results are expressed as mean $\mathrm{cpm} \pm$ standard error of five individual mice. ${ }^{*}$ Significant at $p<0.05$ as compared with KLH alone, ${ }^{* *}$ not significant $(p>0.05)$ as compared with anti-CD3 alone.
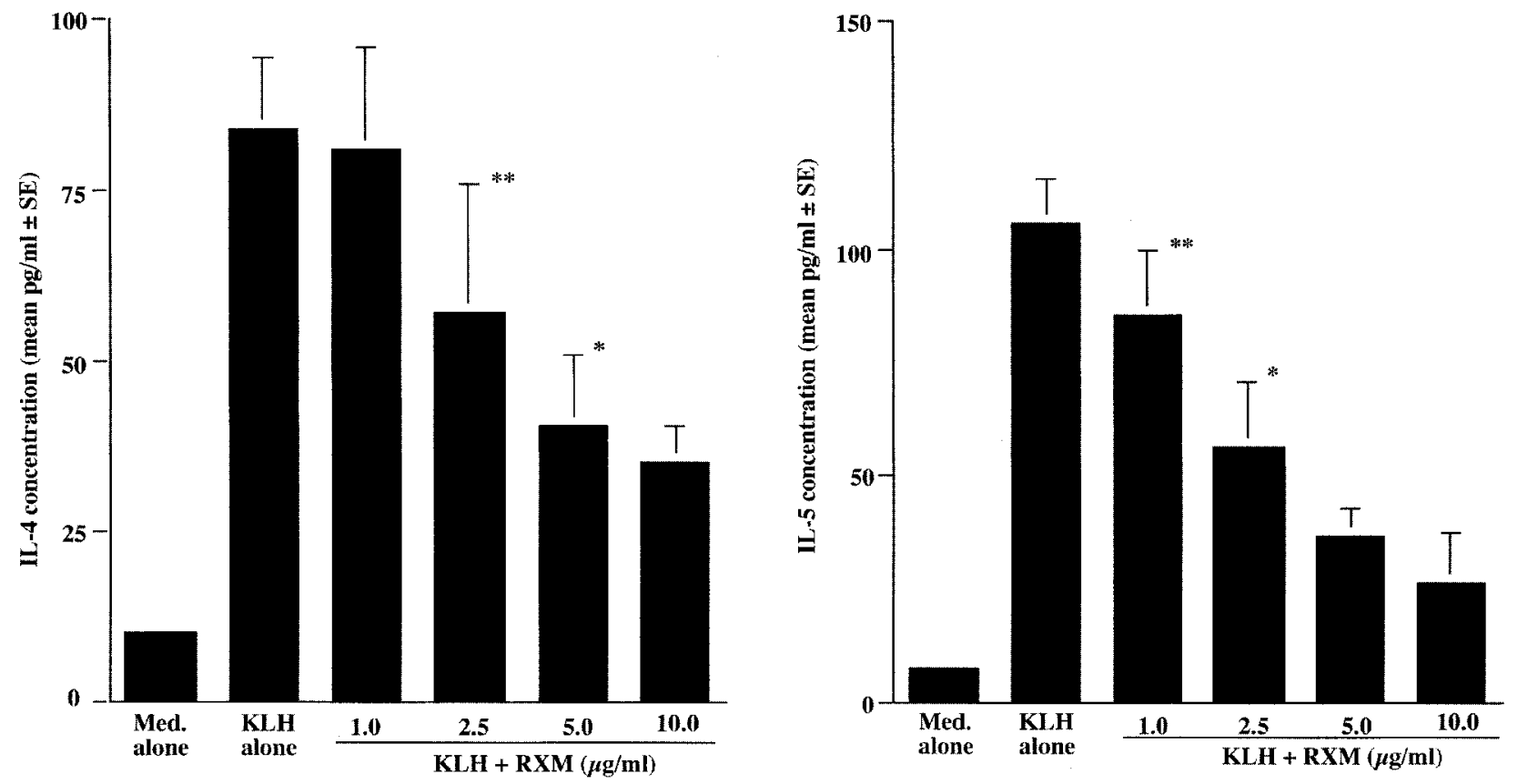

FIG. 2. Influence of RXM on cytokine production from sensitized spleen cells induced by antigenic stimulation in vitro. BALB/c mice were immunized by intraperitoneal injection with $8.0 \mu \mathrm{g} / \mathrm{ml}$ of hemocyanin $\mathrm{KLH}$ absorbed to $4.0 \mathrm{mg}$ of aluminum hydroxide in a volume of $0.5 \mathrm{ml}$. Spleen cells $\left(1 \times 10^{5}\right.$ cells $\left./ 0.1 \mathrm{ml}\right)$ prepared from mice 10 days later were stimulated with $100.0_{\mu} \mathrm{g} / \mathrm{ml}$ of $\mathrm{KLH}$ in the presence of various concentrations of RXM for $24 \mathrm{~h}$. Cytokine concentrations in culture supernatants were examined by ELISA. Data represent the mean $(\mathrm{pg} / \mathrm{ml}) \pm$ standard error of five individual mice. ${ }^{*}$ Not significant $(p>0.05)$ as compared with KLH alone, ** significant at $p<0.01$ as compared with KLH alone. 


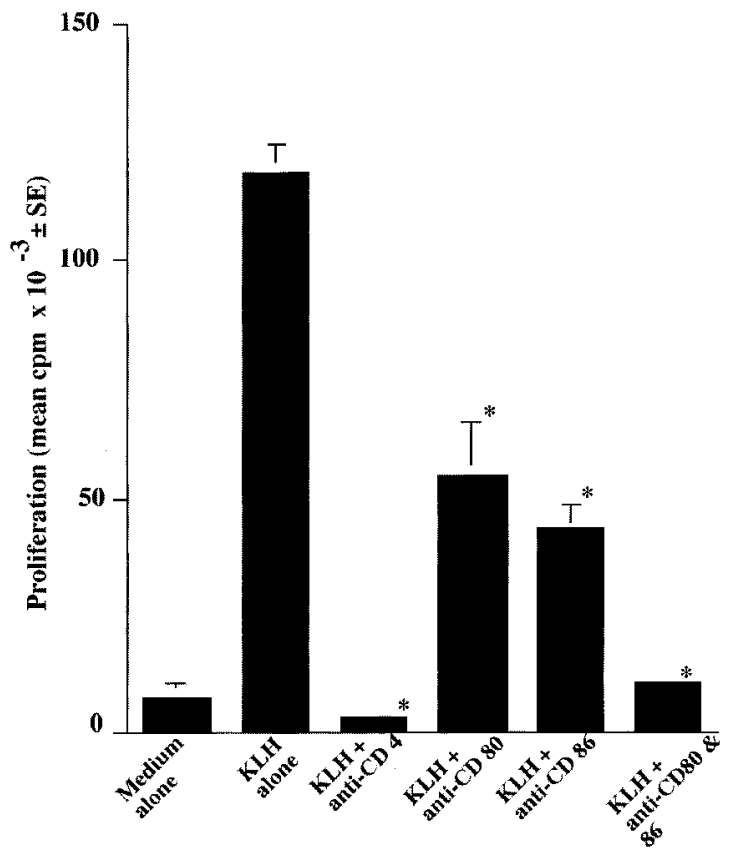

FIG. 3. Suppressive activity of anti-CD80 and anti-CD86 monoclonal antibodies on antigen-induced spleen cell proliferation. BALB/c mice were immunized by intraperitoneal injection with $8.0 \mu \mathrm{g} / \mathrm{ml}$ of hemocyanin (KLH) absorbed to $4.0 \mathrm{mg}$ of aluminium hydroxide in a volume of $0.5 \mathrm{ml}$. Spleen cells prepared 10 days later were cultured with either antiCD80 or anti-CD86, or anti-CD80 and anti-CD86 for $72 \mathrm{~h}$, which were stimulated with $100.0 \mu \mathrm{g} / \mathrm{ml}$ of $\mathrm{KLH}$. The cell proliferation was assessed by measuring incorporation of $1.0 \mu \mathrm{Ci}$ of ${ }^{3} \mathrm{H}$-thymidine for $8 \mathrm{~h}$. The results were expressed as mean $\mathrm{cpm} \pm$ standard error of five individual mice. *Significant at $p<0.001$ as compared with KLH alone.

The data in Fig. 2 clearly show the dose-dependent suppressive effects of RXM on IL- 4 and IL-5 production. The statistically significant suppression was observed when cells were cultured in the presence of more than $5.0 \mu \mathrm{g} / \mathrm{ml}$ of RXM. The fourth experiments were carried out to examine the influence of blockade of co-stimulatory molecules on antigen-induced spleen cell proliferation. Spleen cells prepared from immunized mice were cultured with $100.0 \mu \mathrm{g} / \mathrm{ml}$ of hemocyanin and $5.0 \mu \mathrm{g} / \mathrm{ml}$ of mAbs. As shown in Fig. 3 , addition of either anti-CD80 $\mathrm{mAb}$ or anti-CD86 $\mathrm{mAb}$ into cell cultures significantly suppressed the proliferative response of spleen cells induced by antigenic stimulation. The suppressive activity of these two antibodies was further strengthened when twomAbs were added simultaneously (Fig. 3).

\section{Influence of RXM on co-stimulatory molecule expression in vitro}

The present study was designed to examine the influence of RXM on co-stimulatory molecule expressions on splenic B cells. Spleen cells prepared from mice immunized with hemocyanin were cultured in the presence of $100.0 \mu \mathrm{g} / \mathrm{ml}$ of hemocyanin and

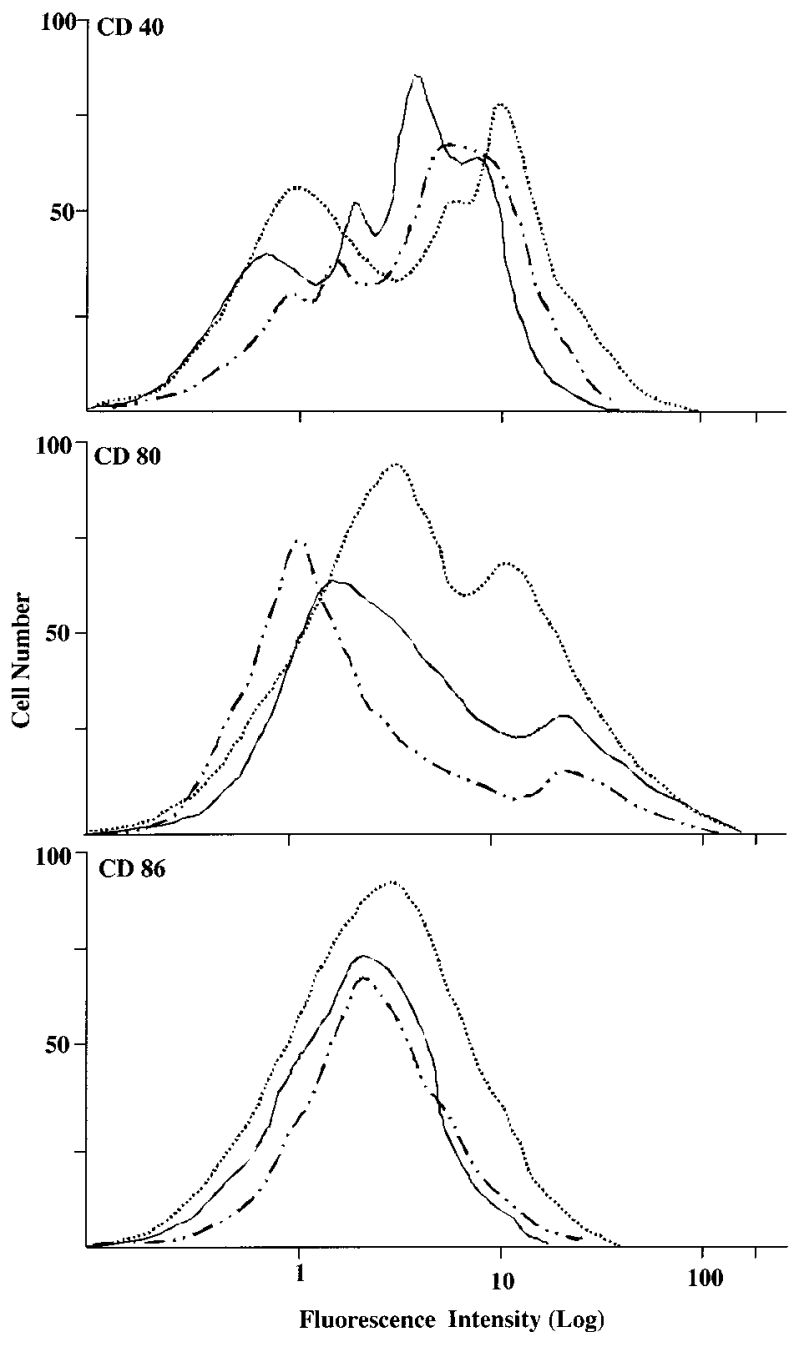

FIG. 4. Influence of RXM on co-stimulatory molecule expressions induced by antigenic stimulation in vitro. BALB/c mice were immunized by intraperitoneal injection with $8.0 \mu \mathrm{g} / \mathrm{ml}$ of hemocyanin absorbed to $4.0 \mathrm{mg}$ of aluminum hydroxide in a volume of $0.5 \mathrm{ml}$. Spleen cells prepared mice 10 days after immunization were cultured with $5.0 \mu \mathrm{g} / \mathrm{ml}$ of RXM and $100.0 \mu \mathrm{g} / \mathrm{ml}$ of hemocyanin for $24 \mathrm{~h}$. The expression was analyzed by flow cytometer: (-) cultured without antigen, $(\cdots \cdots)$ cultured with antigen, $(-\cdots, \cdots-)$ cultured with antigen and RXM.

$5.0 \mu \mathrm{g} / \mathrm{ml}$ of RXM for $24 \mathrm{~h}$. The cultured B cells were stained with FITC-labeled mAbs against co-stimulatory molecules and the expression of CD40, CD80 and CD86 examined by flow cytometer. In flow cytometry, we gated and analyzed the lymphocyte position/population of scattered dots of cultured cells in the display of a computer. Figure 4 shows one typical profile among results obtained in three different experiments of mice immunized by hemocyanin. Addition of RXM into cell cultures at a dose of $5.0 \mu \mathrm{g} / \mathrm{ml}$ remarkably suppressed CD80 and CD86 expressions, which were enhanced by antigenic stimulation in vitro. RXM also exerted inhibitory effects on CD40 expression in response to antigenic stimulation in vitro (Fig. 4). 

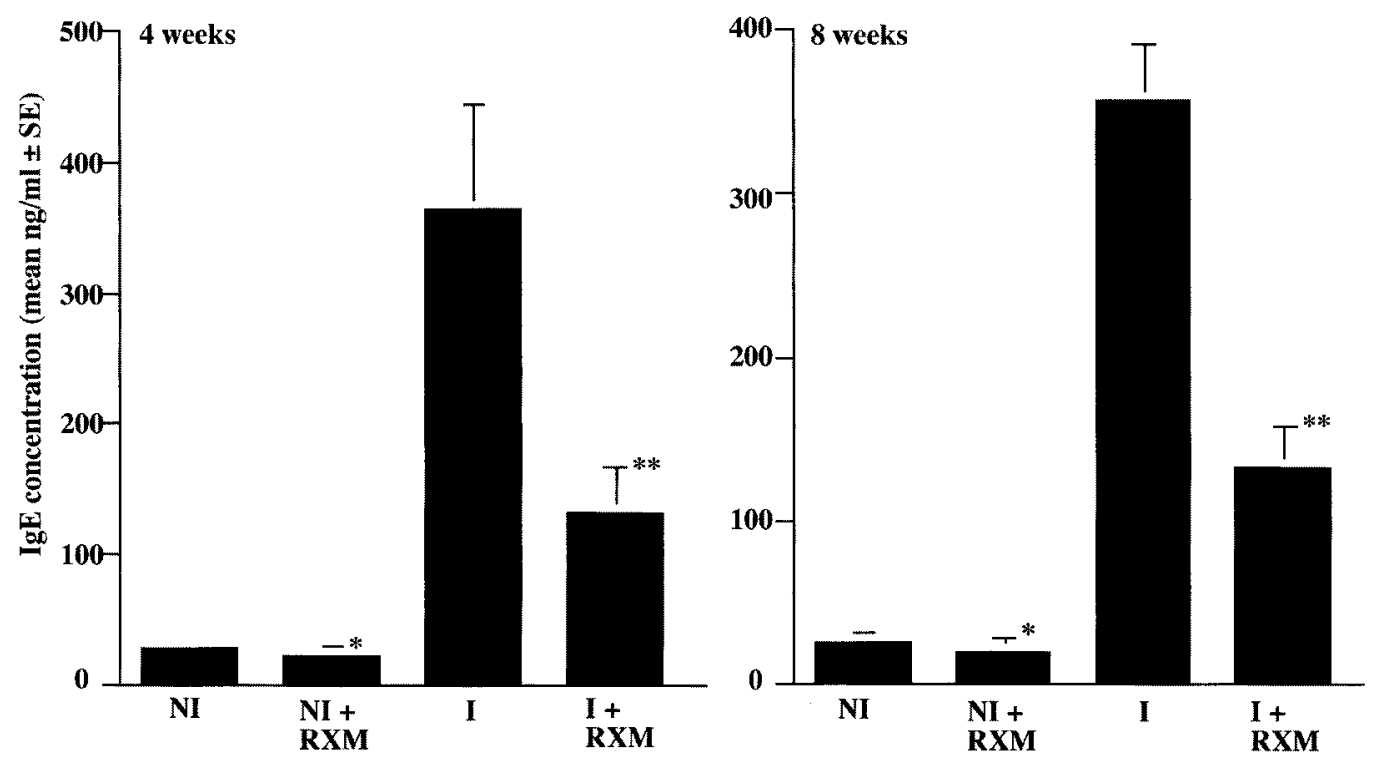

FIG. 5. Influence of oral RXM treatment on IgE production in vivo. BALB/c mice were immunized by intraperitoneal injection with $8.0 \mu \mathrm{g} / \mathrm{ml}$ of hemocyanin absorbed to $4.0 \mathrm{mg}$ of aluminum hydroxide in a volume of $0.5 \mathrm{ml}$. The mice were orally administered with $2.5 \mathrm{mg} / \mathrm{kg}$ of RXM once a day for 4 or 8 weeks starting 7 days after immunization. Serum IgE levels were assayed by ELISA. Data represent the mean $(\mathrm{ng} / \mathrm{ml}) \pm$ standard error of five individual mice. NI, Non-immunized control; I, immunized. * Not significant $(p>0.05)$ as compared with control, ** significant at $p<0.001$ as compared immunized mice.

\section{Influence of RXM on IgE production in vivo}

The present study was designed to examine the influence of RXM treatment on IgE production in immunized mice. As shown in Fig. 5, treatment of mice with $2.5 \mathrm{mg} / \mathrm{kg}$ of RXM once a day for 4 and 8 weeks caused significant inhibition of IgE production, which was upregulated by hemocyanin immunization $(p<0.001)$.

\section{Influence of RXM on co-stimulatory molecule expression in vivo}

The final set of experiments was designed to examine the influence of RXM on co-stimulatory molecule expression in vivo. To do this, mice were treated orally with RXM $(2.5 \mathrm{mg} / \mathrm{kg})$ once a day for 4 or 8 weeks. These RXM-treated mice were injected intraperitoneally with $8.0 \mu \mathrm{g} / \mathrm{ml}$ of hemocyanin absorbed to $4.0 \mathrm{mg}$ of aluminum hydroxide, and spleen cells were prepared from mice $24 \mathrm{~h}$ later. Splenic B cells were then isolated and examined for CD40, CD80 and CD86 expressions by flow cytometer. One typical result of four different mice is shown in Figs 6 and 7 . As shown in Fig. 6 (left panel), CD40 expression was markedly enhanced by antigenic stimulation in vivo, which was suppressed by oral administration of RXM for 4 weeks. However, CD80 and CD86 expressions were scarcely affected by antigenic stimulation and RXM treatment. In a case of pre-sensitized mice (Fig. 6 , right panel), in addition to CD40 expression, CD86 (but not CD80) expression was enhanced by secondary antigenic stimulation in vivo and these molecule (CD40 and CD86) expressions were suppressed by oral RXM treatment for 4 weeks. We further examined the influence of RXM treatment for 8 weeks on CD molecule expressions. As shown in Fig. 7 (left panel), antigenic stimulation in non-sensitized mice caused drastic effect on CD40 expression, and this was suppressed by RXM treatment. The data in Fig. 7 (left panel) also showed that oral RXM treatment could suppress CD86 (but not CD80) expressions, which was clearly enhanced by antigenic stimulation in vivo. In pre-sensitized mice, antigenic stimulation caused enhancement of all CD molecule expressions examined, and they were clearly suppressed by RXM treatment (Fig. 7, right panel).

\section{Discussion}

Several studies have shown that long-term administration of macrolide antibiotics can favorably modify the clinical condition of inflammatory diseases. ${ }^{1-7}$ Although the precise therapeutic mechanisms of macrolides are not well understood, it is speculated that the efficacy of macrolide treatment is owing to anti-inflammatory rather than anti-bacterial effects of the agents. ${ }^{8-10}$ Many of the steps in the inflammatory cascade are reported to be controlled by soluble regulatory molecules (serotonin, histamine and leukotriene, etc.) known as inflammatory or chemical mediators. ${ }^{11}$ Furthermore, much evidence clearly shows that $\mathrm{T}$ cells play a pivotal role in initiation, driving and maintenance of all these processes by elaboration of several types of cytokines. ${ }^{9-11}$ There is now also the established concept that the CD28/B7 co-stimulatory pathway is essential for full activation 

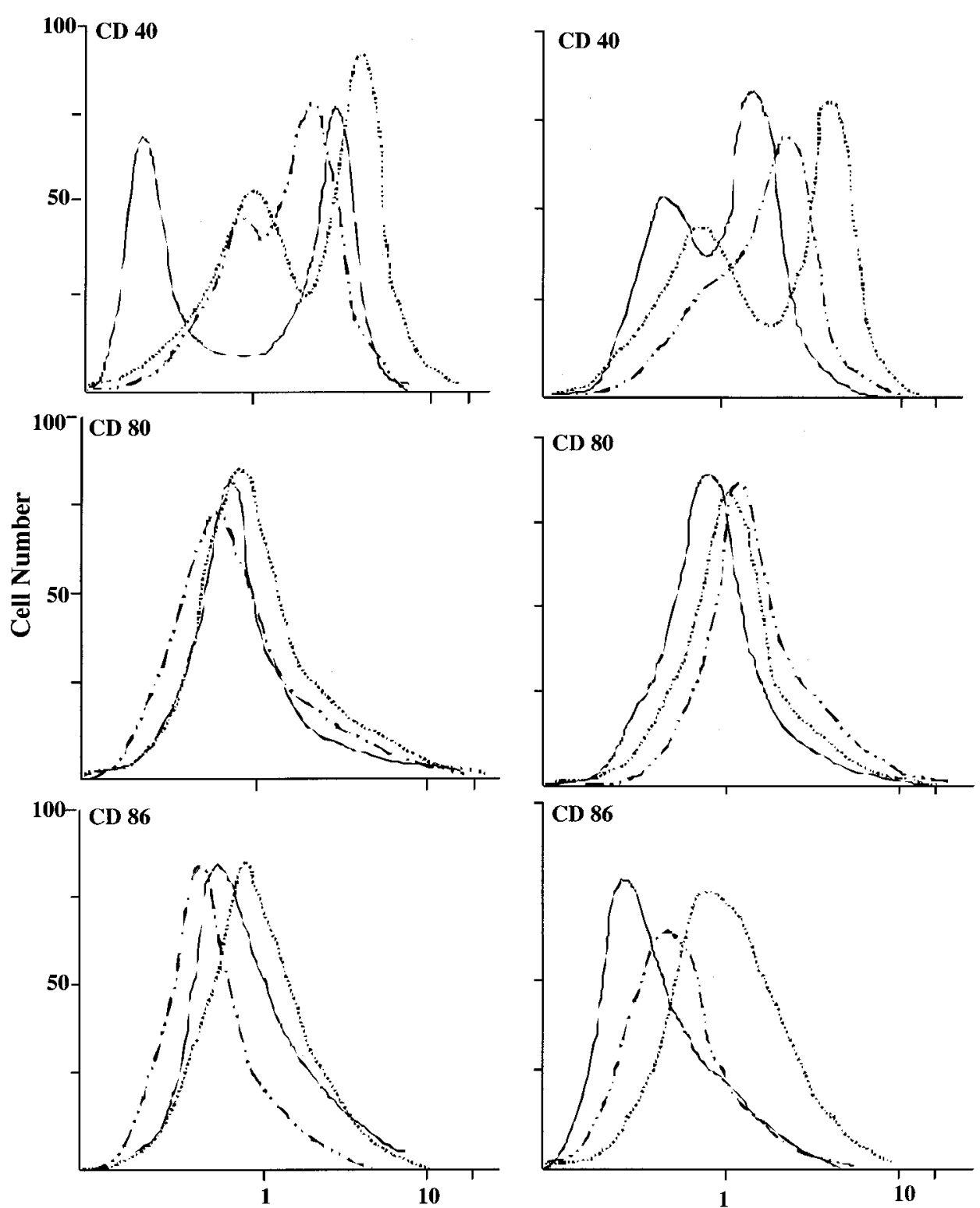

Fluorescence Intensity ( $\log )$

FIG. 6. Influence of oral RXM treatment for 4 weeks on co-stimulatory molecule expressions induced by antigenic stimulation in vivo. BALB/c mice were immunized by intraperitoneal injection with $8.0 \mu \mathrm{g} / \mathrm{ml}$ of hemocyanin absorbed to $4.0 \mathrm{mg}$ of aluminum hydroxide in a volume of $0.5 \mathrm{ml}$. The mice were orally administered with $2.5 \mathrm{mg} / \mathrm{kg}$ of RXM once a day for 4 weeks starting 7 days after immunization. Splenic B cells were prepared from mice $24 \mathrm{~h}$ after challenging immunization. The expression was analyzed by flow cytometer: (-) non-treated and non-challenged control, $(\cdots \cdots)$ non-treated and challenged, $(-\cdots-\cdots-)$ treated and challenged. Left panels, non-immunized mice; right panels, immunized mice.

of $\mathrm{T}$ cells, including proliferation and cytokine secretion. ${ }^{12,13}$ Yet the action of RXM on the co-stimulatory pathway is poorly understood. ${ }^{22}$ To examine the influence of RXM on the co-stimulatory pathway, it was first tested on the response of lymphocytes to in vitro antigenic stimulation by examining cell proliferation and cytokine production. The present data (Figs 1 and 2) clearly show the antigen-specific, but not non-specific, inhibitory effects of RXM on cell activation. It is also suggested that the inhibitory action of RXM on cell activation is not due to cytotoxic effects of the agent to splenic $\mathrm{T}$ cells, since non-specific cell activation induced by anti-CD3 mAb stimulation is not influenced by RXM (Fig. 1B). An optimal antigen-specific T-cell activation requires two distinct signals. Activation of T cells by signals through the T-cell receptor in the presence of co-stimulatory signals results in T-cell clonal expansion and the induction of effector functions such as the production of cytokines. ${ }^{12-15}$ On the contrary, the interaction of $\mathrm{T}$ cells with antigen in the absence of co-stimulatory signals is not a neutral event but, rather, leads to induced unresponsiveness or to cell death. ${ }^{12,13}$ It is reported that RXM not only interfered with, but also 


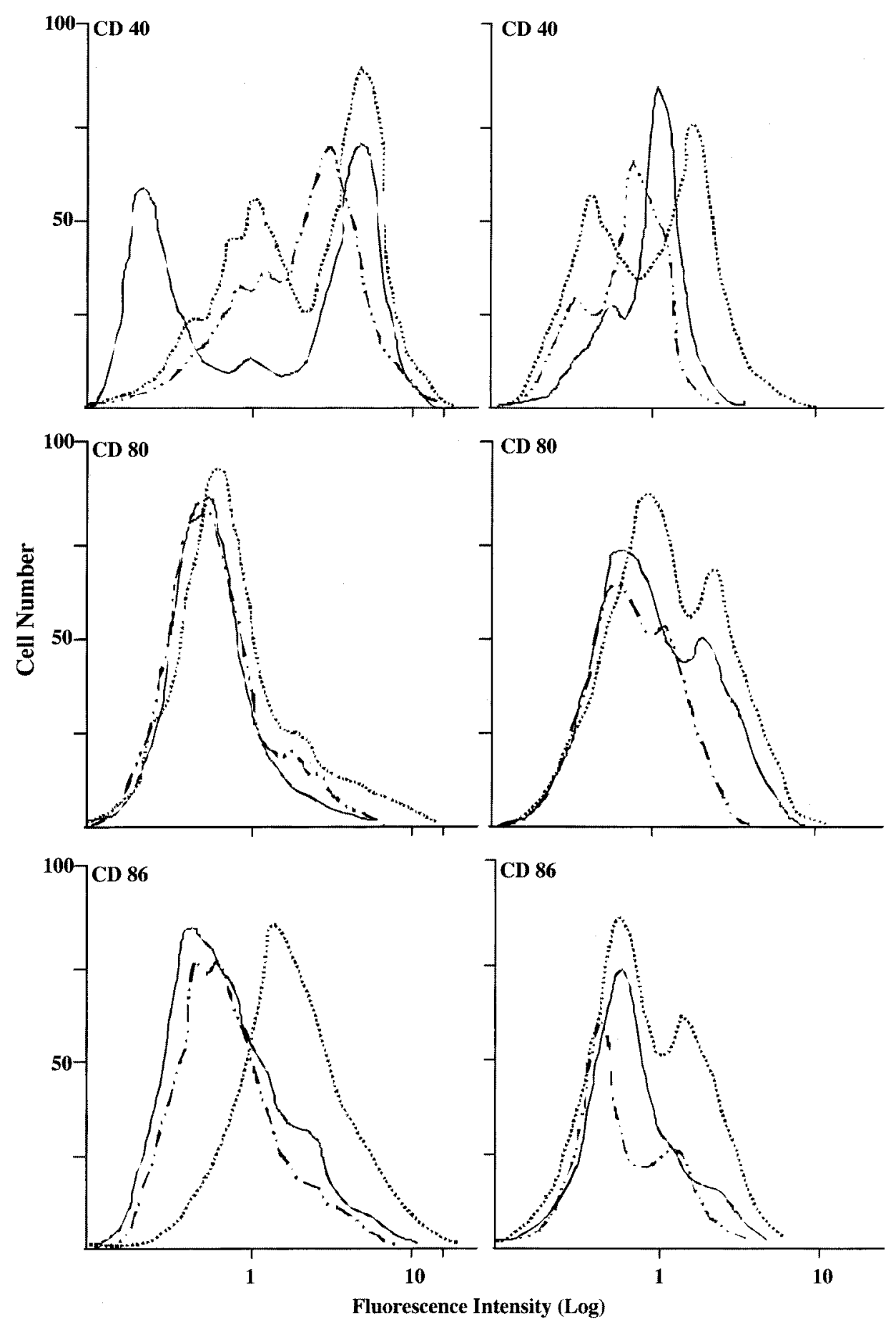

FIG. 7. Influence of oral RXM treatment for 8 weeks on co-stimulatory molecule expressions induced by antigenic stimulation in vivo. BALB/c mice were immunized by intraperitoneal injection with $8.0 \mu \mathrm{g} / \mathrm{ml}$ of hemocyanin absorbed to $4.0 \mathrm{mg}$ of aluminum hydroxide in a volume of $0.5 \mathrm{ml}$. The mice were orally administered with $2.5 \mathrm{mg} / \mathrm{kg}$ of RXM once a day for 8 weeks starting 7 days after immunization. Splenic B cells were prepared from mice $24 \mathrm{~h}$ after challenging immunization. The expression was analyzed by flow cytometer: $(-)$ non-treated and non-challenged control, $(\cdots \cdots)$ non-treated and challenged, $(-\cdots-\cdots-)$ treated and challenged. Left panels, non-immunized mice; right panels, immunized mice.

enhanced, the capacity of activated antigen presenting cells $\mathrm{C}$ to present antigenic properties. ${ }^{25}$ These reports and the data in Fig. 3 may suggest that RXM suppressed co-stimulatory molecule expressions and resulted in inhibition of cell activation by antigenic stimulation in vitro. Therefore, we next examined the influence of RXM on co-stimulatory molecule expressions on splenic B cells. The present results clearly show that RXM could suppress the expression of costimulatory molecules CD80 and CD86 on sensitized splenic B cells, which were enhanced by in vitro stimulation with antigen (Fig. 5). 
De Boer et al. showed that CD80 could act as a costimulatory molecule for the production of IL- 4 and IL-5, which are essential cytokines for development and maintenance of inflammatory diseases, from human peripheral blood $\mathrm{T}$ cells in response to stimulation with mAb directed at the T-cell receptor. ${ }^{26}$ It is also showed that CTLA- 4 immunoglobulin fusion protein (CTLA-4Ig), a blocker of CD28/B7 co-stimulation, could block allergen-specific proliferation and $\mathrm{T}$ helper cell type 2 cytokine (IL- 4 and IL-5) production by peripheral blood mononuclear cells from atopic donors. ${ }^{27}$ In support of these in vitro studies, several in vivo studies have noted that blockade of CD28/B7 co-stimulation preferentially inhibits Th2 cell responses, while leaving $\mathrm{T}$ helper cell type 1 responses intact. $^{28-30}$ With regard to the influence of CD80/ CD86 on effector cell (mainly eosinophils) functions, a lot of reports show that intranasal administration of CTLA4Ig inhibited eosinophil accumulation in lungs and airway tracts induced by aerosol provocation of allergen. ${ }^{19,31,32}$ It is also reported that airway administration of anti-CD86 mAb inhibited eosinophil influx, IgE production, and $\mathrm{T}$ helper cell type 2 cytokine secretion comparable in magnitude with that observed with CTLA-4Ig. ${ }^{19}$ Judging from these reports, the present results (Fig. 4) suggest that RXM exerts an attenuating effect on inflammatory diseases through inhibition of co-stimulatory molecule expressions. However, before drawing the conclusion that oral RXM treatment suppress co-stimulatory molecule expressions and results in favorable modification of the inflammatory diseases, it is necessary to examine whether oral administration of RXM could inhibit costimulatory molecule expressions in response to antigenic stimulation in vivo.

IgE-dependent stimulation of tissue mast cells and their circulating counterparts, basophils, is well known to constitute one of the major effector systems of allergic diseases that reflect the immunologically induced inflammatory responses in the organ or tissue involved. It is proposed that the prevention or suppression of IgE antibody formation to allergens is one of the fundamental treatments of inflammatory diseases including hay fever, allergic asthma and urticaria. ${ }^{33}$ IgE synthesis is recognized to be dependent on a complex process involving several cellular and molecular interactions. ${ }^{34,35}$ The initial step for the development of IgE-producing plasma cells is $\varepsilon^{\text {-germ- }}$ line transcription by IL- 4 and IL-13. ${ }^{34}$ The second is provided by engagement of CD40 and CD40 ligand, which is important for switch recombination to IgE synthesis in B cells. ${ }^{35}$ These reports suggest that the suppressive effects of RXM on CD40 expressions might be contribute, in part, to the therapeutic mode of action of RXM on inflammatory diseases.

Although the present results clearly suggest that RXM inhibits co-stimulatory molecule expressions on splenic lymphocytes in response to antigenic stimula- tion in vitro and in vivo, the precise mechanisms are not understood at present. Pharmacological studies revealed that erythromycin ${ }^{36}$ and RXM (M. Suzuki, unpublished observations 2001) prevent calcium cation influx into cells, resulting in reduced permeability of the cell membrane and in inhibition of expression of protein synthesized in the cytosol. It is also reported that erythromycin increases the intracellular cyclic adenosine monophosphate (cAMP) level. ${ }^{37}$ Elevation of the intracellular cAMP level elaborates an important downregulatory signal in the release of proteins synthesized in the cytosole. ${ }^{38}$ From these reports, it is possible that RXM prevents accumulation of the calcium cation in the cytosol and enhances the intracellular cAMP level, resulting in inhibition of CD molecule expressions. Further experiments are needed to clarify this point.

\section{References}

1. Plewig G, Schopf E. Anti-inflammatory effects of antimicrobial agents: an in vivo study. $J$ Invest Dermatol 1975; 65: 532-536.

2. Miyatake H, Suzuki K, Taki F, Takagi K, SatakeT. Effect of erythromycin on bronchial hyperresponsiveness in patients with bronchial asthma. Arzneimittelforschung 1991; 41: 552-556.

3. Miyatake H, Taki F, Taniguchi H, Suzuki R, Takagi K, Satake T. Erythromycin reduces the severity of bronchial hyperresponsiveness in asthma. Chest 1991; 99: 670-673.

4. Iino Y, Toriyama M, Kudo K. Erythromycin inhibition of lipopolysaccharide-stimulated tumor necrosis factor alpha production by human monocytes in vitro. Ann Otol Rhinol Laryngol 1992; 101 (Suppl 157): $16-20$

5. Ichikawa $Y$, Ninomiya $H$, Koga $H$. Erythromycin reduces neutrophil and neutrophil-derived elastolytic-like activity in the lower respiratory tract of bronchiolitis patients. Am Rev Respir Dis 1992; 146: 196-203.

6. Jaffe A, Francis J, Rosenthal M, Bush A. Long-term azithromycin may improve lung function in children with cystic fibrosis. Lancet $1998 ; 351$ : 420.

7. Pirzada OM, Taylor CJ. Long-term macrolide antibiotics improve pulmonary function in cyctic fibrosis. Pediatr Pulmonol (Suppl) 1999; 19: 283

8. Miyachi Y, Yoshida A, Imamura S, Niwa Y. Effects of antibiotics on generation of reactive oxygen species. J Invest Dermatol 1986; 86: 449-453.

9. Konno S, Asano K, Kurokawa M, Ikeda K, Okamoto K, Adachi M. Antiasthmatic activity of a macrolide antibiotic, roxithromycin: analysis of possible mechanisms in vitro and in vivo. Int Arch Allergy Immuno 1994; 105: 308-316

10. Suzaki H, Asano K, Ohki S, Kanai K, Mizutani T, Hisamistu T. Suppressive activity of a macrolide antibiotic, roxithromycin, on pro-inflammatory cytokine production in vitro and in vivo. Mediat Inflamm 1999; 8: 199-204.

11. Kay AB. Role of T cells in asthma. Allergy Int 1997; 46: 73-82.

12. Schwartz RH. Costimulation of T lymphocytes: the role of CD28, CTLA-4 and B7/BB1 in interleukin-2 production and immunotherapy. Cell 1992 ; 71: $1065-1068$.

13. Lenschow DJ, Walnus TL, Bluestone JA. CD28/B7 system of T cell costimulation. Ann Rev Immunol 1996; 14: 233-258.

14. Hofer MF, Jirapongsananuruk $\mathrm{O}$, Trumble AE, Leung DYM. Upregulation of B7.2, but not B7.1, on B cells from patients with allergic asthma. $J$ Allergy Clin Immunol 1998; 101: 96-102.

15. Jirapongsananuruk $O$, Hofer MF, Trumble AE, Norris DA, Leung DY. Enhanced expression of B7.2 (CD86) in patients with atopic dermatitis: a potential role in the modulation of IgE synthesis. J Immunol 1998; 160: 4622-4627.

16. Nakada M, Nishizaki K, Yoshino T, Okano M, Masuda Y, Ohta N. CD86 (B7-2) antigen on B cells from atopic patients shows selective, antigenspecific upregulation. Allergy 1998; 53: 527-531.

17. Kawamura MS, Aiba S, Tagami H. The importance of CD54 and CD86 costimulation in T cells stimulated with Candida albicans and Dermatophagoides farinae antigens in patients with atopic dermatitis. Arch Dermatol Res 1998; 290: 603-609.

18. Morikawa $H$, Nagashima $S$. The role of costimulatory molecules (B7-1 and $\mathrm{B} 7-2$ ) on allergen-stimulated B cells in cedar pollinosis subjects. Clin Exp Allergy 2000; 30: 383-392. 
19. Tsuyuki S, Tsuyuki J, Einsle K, Kopf M, Coyle AJ. Costimulation through B7-2 (CD86) is required for the induction of a lung mucosal T helper cell 2 (TH2) immune response and altered airway responsiveness. J Exp Med 1997; 185: 1671-1679.

20. Mark DA, Donovan CE, De Sanctis GT. Both CD80 and CD86 costimulatory molecules regulate allergic pulmonary inflammation. Int Immunol 1998; 10: 1647-1655.

21. Huang Y, Watanabe N, Ohtomo H. The involvement of CD80 and CD86 costimulatory molecules in the induction of eosinophilia in mice infected with Nippostrongylus brasiliensis. Int Arch Allergy Immunol 1998; 117: 2-4.

22. Kawazu K, Kurokawa M, Asano K, Mita A, Adachi M. Suppressive activity of a macrolide antibiotic, roxithromycin on co-stimulatory molecule expression on mouse splenocytes in vivo. Mediat Inflamm 2000; 9: 39-43.

23. Ito J, Asano K, Tryka E, Kanai K, Yamamoto S, Hisamitsu T, Suzaki H. Suppressive effects of co-stimulatory molecule expression on mouse splenocytes by anti-allergic agents in vitro. Mediat Inflamm 2000; 9: $69-75$.

24. Morimoto C, Torimoto Y, Levinson G, Rudd CE, Schrieber M, Dang NH, Schlossman SF. 1F7, a novel cell surface molecule involved in helper function of CD4 cells. J Immunol 1989; 143: 3430-3439.

25. Sacha PT, Zaremba ML, Jakoniuk P. The influence of antibiotics on phagocytic and bacteriocidal activity of rabbit peritoneal macrophages stimulated by filtrates of cultured T-lymphocytes. Med Dosw Microbiol 1999; 51: 399-412.

26. De Boer M, Kasran A, Kwekkenboom J, Walter $H$, Vandenberghe $P$, Ceuppens JL. Ligation of B7 with CD28/CTLA4 on T cells results in CD40 ligand expression, interleukin 4 secretion, and efficient help for antibody production by B cells. Eur J Immunol 1993; 23: 3120-3125.

27. Van Neerven RJJ, Van De Polo MM, Van Der Zee JS, Stiekema FE, De Boer M, Kapsenberg ML. Requirement of CD28-CD86 costimulation for allergen-specific T cell proliferation and cytokine expression. Clin Exp Allergy 1998; 28: 808-816.

28. Corry DB, Reiner SL, Linsley PS, Locksley RM. Differential effects of blockade of CD28-B7 on the development of Th1 or Th2 effector cells in experimental leishmaniasis. J Immunol 1994; 153: 4142-4148.
29. Kundig TM, Shahinian A, Kawai K. Duration of TCR stimulation determines costimulatory requirement of T cells. Immunity 1996; 5 : 41-52.

30. Harris NL Peach RJ, Ronchese F. CTLA4-Ig inhibits optimal T helper 2 cell development but not protective immunity or memory response to Nippostrongylus brasiliensis. Eur J Immunol 1999; 29: 311-316.

31. Harris N, Peach R, Naemura J, Linsky PS, Gros GL, Ronchese F. CD80 costimulation is essential for the induction of airway eosinophilia. $J \operatorname{Exp}$ Med 1997; 185: 177-182.

32. Sato J, Asakura K, Murakami M, Uede T, Kataura A. Topical CTLA4-Ig suppresses ongoing mucosal immune response in presensitized murine model of allergic rhinitis. Int Arch Allergy Immunol 1999; 119: 197-204.

33. Ishizaka K, Iwata M, Carini C, Katamura K, Takeuchi T. Antigen-specific factors in IgE regulation. In: Sorg $\mathrm{C}$, ed. Cytokines Regulating the Allergic Response. Basel: Karger, 1989: 1-18.

34. Loh RKS, Jabara HH, Geha RS. Disodium cromoglycate inhibits $S_{\vartheta}$ to $S_{\varepsilon}$ deletional switch recombination and IgE synthesis in Human B cell. J Exp Med 1994; 180: 663-671.

35. Worm M, Henz BM. Molecular regulation of human IgE synthesis. J Mol Med 1997; 75: 440-447.

36. Zhao DM, Xue HH, Chida K, Suda T, Oki Y, Kanai M, Uchida C, Ichikawa A, Nakamura H. Effect of erythromycin on ATP-induced intracellular calcium response in A549 cells. Am J Physiol Lung Cell Mol Pbysiol 2000; 278: 724-736.

37. Depoortere I, Peeters TL. Transduction mechanism of motilin and motilides in rabbit duodenal smooth muscle. Regulat Pept 1995; 55: 227-235.

38. Endres S, Fulle HJ, Sinha B, Stoll D, Dinarello CA, Gerzer R, Weber PC. Cyclic nucleotides differentially regulate the synthesis of tumor necrosis factor-a and interleukin-1b by human mononuclear cell. Immunology 1991; 72: 56-60.

Received 2 April 2002

Accepted 2 May 2002 


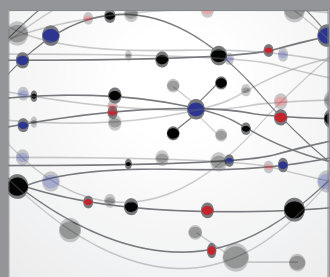

The Scientific World Journal
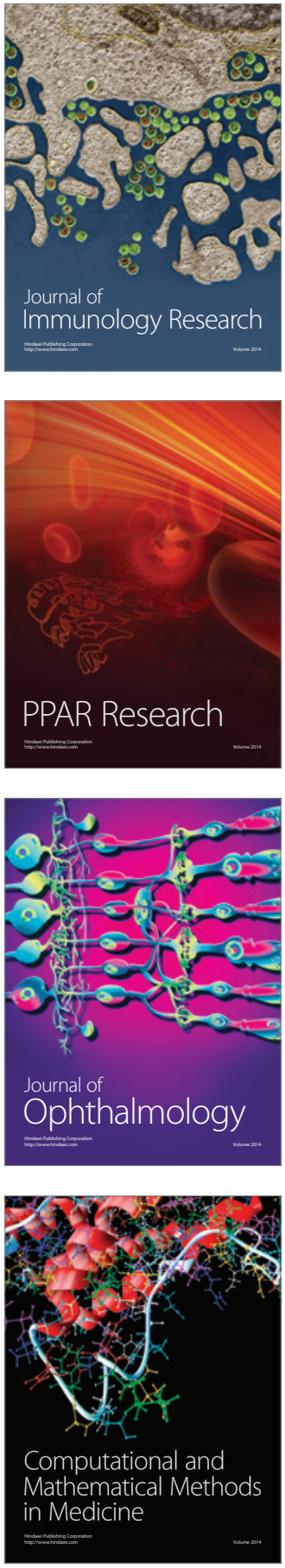

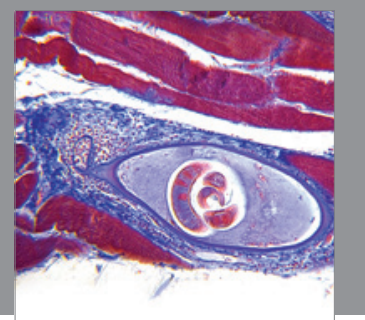

Gastroenterology

Research and Practice
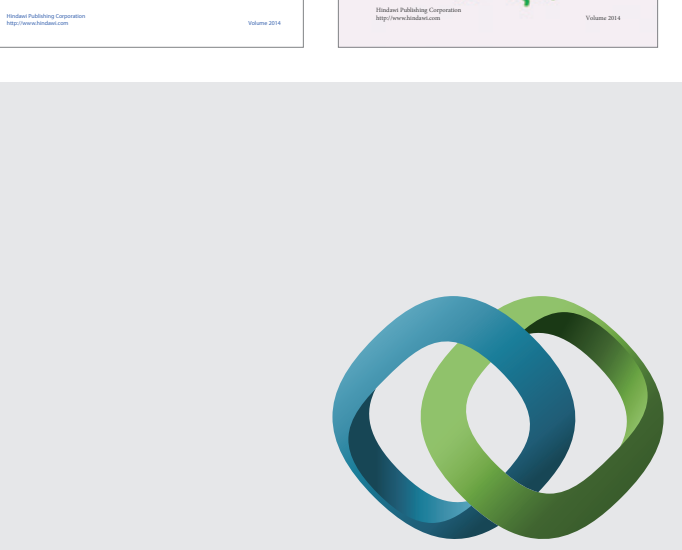

\section{Hindawi}

Submit your manuscripts at

http://www.hindawi.com
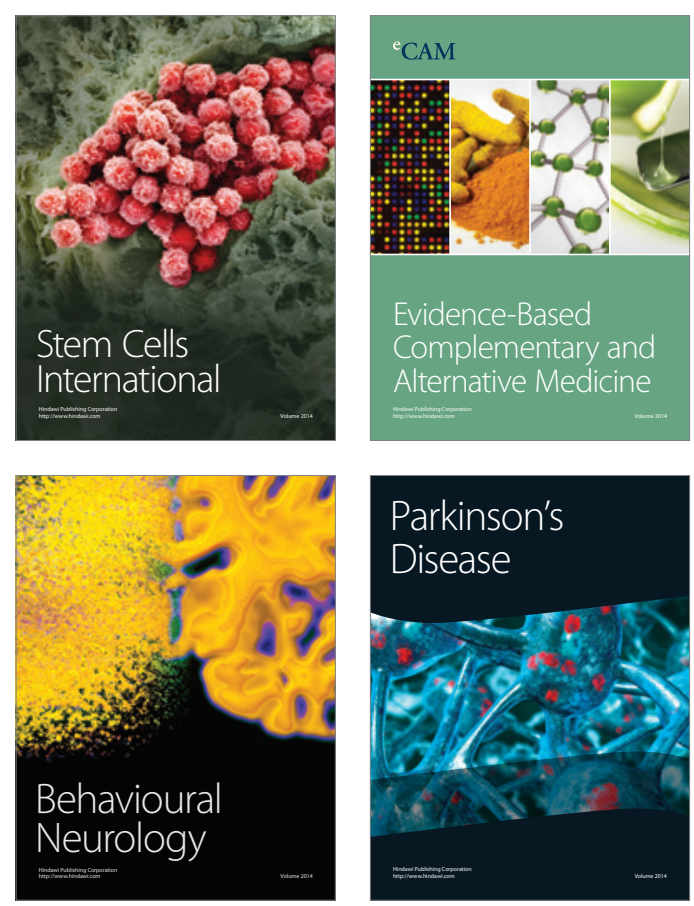

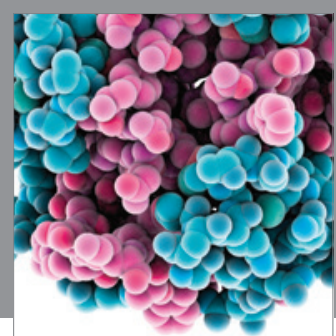

Journal of
Diabetes Research

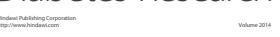

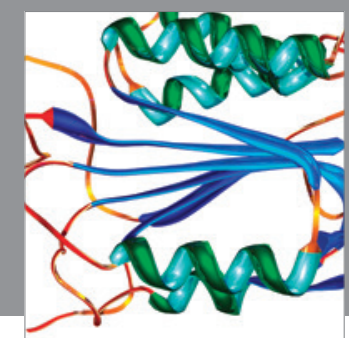

Disease Markers
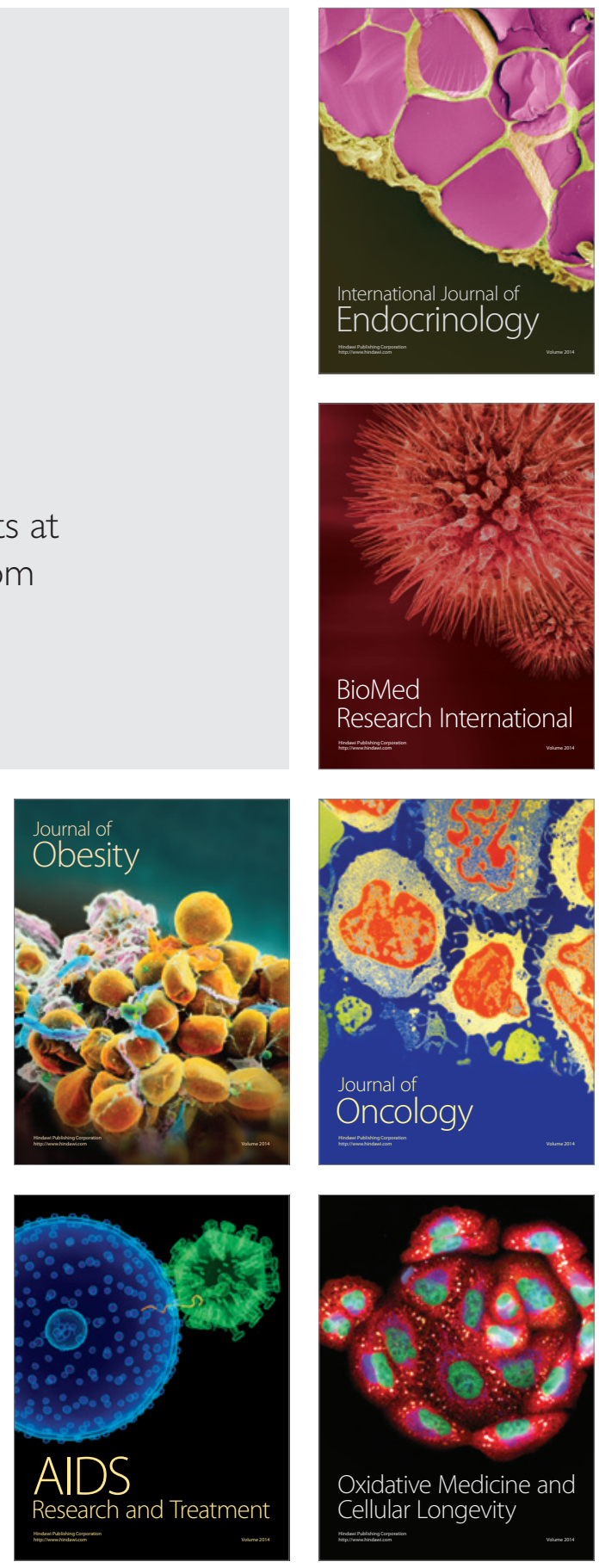